\title{
DInSAR based land deformation detection in the karst landscape of Gunung Sewu
}

\author{
Ridwan Arif Pambudi, Rijali Isnain Haripa \\ Department of Geography, Faculty of Mathematics and Natural Sciences, Universitas Indonesia, \\ Depok, Indonesia
}

\begin{abstract}
Hydrologic element specifically precipitation was fathomed to contribute in land deformation of karst landscape. Cempaka Tropical Cyclone (TC) had ensued in the last of 2017 in the Indian Ocean implicated to a high rate of rainfall upon the karst landscape of Gunung Sewu. This research aimed to identify the areas where sustained of land deformation due to the Cempaka TC. This research used a method of Differential Interferometry Synthetic Aperture Radar (DInSAR) by utilising a pair of Sentinel-1A satellite imageries to obtain the information of land deformation. The research result demonstrated the karst landscape of Gunung Sewu encountered land deformation after the Cempaka TC had impinged it. The land deformation occurred in the northern region of Gunung Sewu karst landscape in the forms of land uplifting with a range of $1-2 \mathrm{~mm} /$ year $\left(115.36 \mathrm{~km}^{2}\right)$ and gradually became a land subsidence with a range of $-1--4 \mathrm{~mm} /$ year $\left(989.25 \mathrm{~km}^{2}\right)$ in the southern region of Gunung Sewu karst landscape. This finding was important as a preliminary research to mitigate the hazards and conserve the karst landscape of Gunung Sewu upon the threats of extreme weather in the future.
\end{abstract}

\section{Introduction}

Land deformation as a process of karst evolution is commonly affected by tectonic control $[1,2]$. However, the cutting edge of researches demonstrate that surface and subsurface processes either in natural or anthropogenic have contributed to tectonic deformation in the long term [3-5]. Rainfall besides as a driven factor of karstification is also suspected as a trigger of land deformation in karst landscape [5-8].

Cempaka Tropical Cyclone (TC) which had been formed on 27 November 2017 in the Indian Ocean, $100 \mathrm{~km}$ southern of Cilacap District $\left(8,6^{\circ} \mathrm{S}\right.$ dan $\left.110,8^{\circ} \mathrm{E}\right)$ increased rainfall more than $150 \mathrm{~mm} /$ day in the range of 28-29" November 2017 on several districts and cities in the south region of East Java, Central Java, and Special Region of Yogyakarta [9-11]. Besides caused flood inundation, the extreme rainfall also induced landslide and land subsidence in the karst landscape of Gunung Sewu [12]. The land subsidence is prevalent occur in karst landscape since its high rate dissolution of the lithological element (such as soluble carbonate and evaporite rocks) in the subsurface as an effect of the chemistry process [13-16].

\footnotetext{
${ }^{*}$ Corresponding author: ridwan.arif@ui.ac.id
} 
Nowadays, the determining of land deformation rate is able using either GNSS CORS or Synthetic Aperture Radar (SAR) [17-19]. SAR emits an electromagnetic wave and generates two measurements which are amplitude and phase [20]. Interferometry SAR (InSAR) utilises the phase information in SAR imagery which very sensitive towards distance variation, is enable used for measurement of land deformation [17]. The principle of InSAR in measurement of land deformation is utilising information of differential phase between a pair of SAR satellite imageries which are acquired on two different times from almost similar satellite positions (incidence angle) [3,20,21].

This research aims to identify the karst landscape of Gunung Sewu where suffered land deformation had been induced by Cempaka TC with Differential InSAR (DInSAR). Consider that TCs which occur in the Indian Ocean take effect often towards extreme rainfall in the south region of Indonesia, then this research result could be a preliminary research to mitigate the hazards and conserve karst landscape of Gunung Sewu towards extreme weathers in the future [22-24].

\section{Research Area}

Karst landscape of Gunung Sewu is part of South Java Mountain Range (Fig. 1) [25]. This karst landscape has $1,315 \mathrm{~km}^{2}$ area and stretches upon three provinces which are East Java, Central Java, and Special Region of Yogyakarta. It is a tropical karst landscape formed by a combination of tectonic, erosion, denudation and deposition processes which have been occurred since Miocene epoch [26]. This karst landscape is dominated by Wonosari-Punung Formation (Tmwl) with limestone as a majority of its lithology element [27-29]. It has attained mature stadium of karst genesis, this condition is marked by endokarst morphologies consist of caves and subterranean rivers which are common discovered [30].

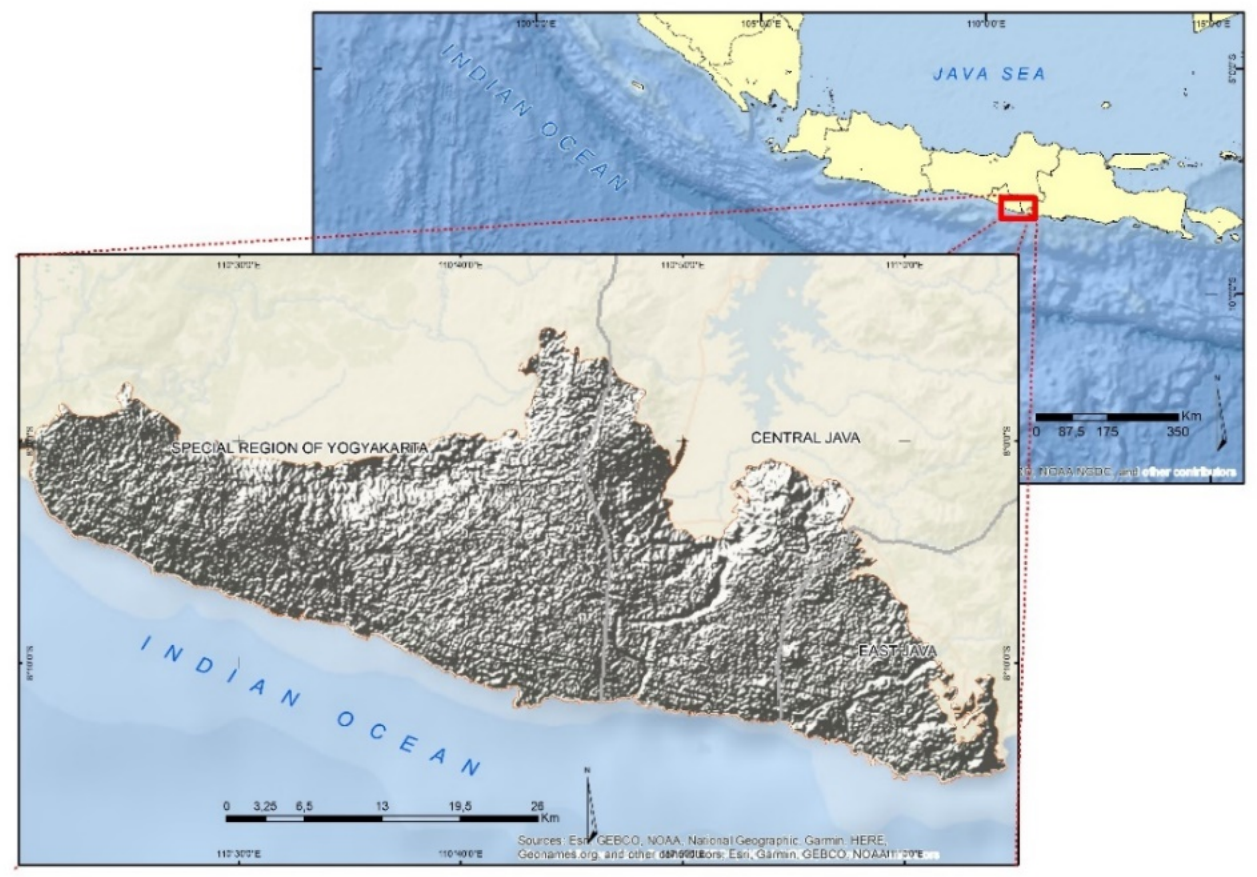

Fig. 1. Research area 


\section{Materials and Methods}

\subsection{Materials}

A pair of Sentinel-1A satellite imageries had been acquired on 15th November 2017 (before Cempaka TC) and 9th December 2017 (after Cempaka TC) were used for obtaining land deformation information in the research area. C-band data of Sentinel-1A satellite imageries are provided by the European Space Agency (ESA) and Shuttle Radar Topography Mission (SRTM) v4.1 data are downloaded from Consortium for Spatial Information (CGIAR-CSI) (http://srtm.csi.cgiar.org/srtmdata/) [31-33]. The SRTM data were utilised to refinement of orbit and eliminate a terrain phase on respective of Sentinel-1A satellite imagery [32,33]. Table 1 shows detailed information of the data were used.

Table 1. Detailed information of Sentinel-1A images and SRTM data

\begin{tabular}{ccc}
\hline Data & Parameters & Description \\
\hline \multirow{4}{*}{ Sentinel- 1A } & Type & Single Looked Complex (SLC) \\
& Imaging mode & Interferometric Wide (IW) Swath \\
& Band and wavelength (cm) & C-Band \& 5.5 \\
& Track number & $127 / 1511$ \\
& Orbit direction & Ascending \\
& Azimuth resolution (m) & 22 \\
& Range resolution (m) & 3.5 \\
& Polarization & VV \\
\hline \multirow{2}{*}{ SRTM } & Resolution (m) & 90 \\
& Positioning accuracy (m) & 20 \\
& Elevation accuracy (m) & 16 \\
\hline
\end{tabular}

\subsection{Methods}

In order to obtain information of land deformation in the karst landscape of Gunung Sewu, a DInSAR method was used for processing a pair of Sentinel-1A satellite imageries in the ENVI SARScape module. The following function (1) is the basis of calculation used in the DInSAR method $[21,34]$.

$$
\Delta \phi=\Delta \phi \text { flat }+\Delta \phi \text { height }+\Delta \phi \text { displacement }+\Delta \phi \text { atmosphere }+\Delta \phi \text { noise }
$$

Where;

$\Delta \phi$ flat

$\Delta \phi$ height

$\Delta \phi$ displacement

$\Delta \phi$ atmosphere

$\Delta \phi$ noise

: The phase contribution of the flat earth;

: Represents topography;

: the part of the phase which represents the ground deformation measured along the line of sight (LOS);

: The contribution of phase caused by the delay of radar wave propagation through the atmosphere;

: $\quad$ Residual noise.

In this study, Sentinel-1A satellite imagery had been acquired on $9^{\text {th }}$ December 2017 was selected as a master image and the satellite imagery of $15^{\text {th }}$ November 2017 as a slave image. Baseline estimation is an optional step to identify the beginning data characteristic and as assessment of interferometric quality $[35,36]$. In order to generate a flattened interferogram, the step of interferogram generation was executed, where the constant phase and topographic phase were eliminated by the SRTM DEM data $[35,36]$. On the step of adaptive filter and 
coherence generation, a Goldstein filtering method was selected to reduce phase noise of the flattened interferogram [36,37]. After that, MCF method was implemented into a phase of unwrapping [36]. The next step, phase to displacement conversion step was carried out with fifteen points were inputted manually as GCPs by avoiding the areas where had high topography fringes and unwrapped phase errors [35,38]. The final step is refinement and reflattening step, this step was done by converted phase to height and geocoded into a map projection [35-37].

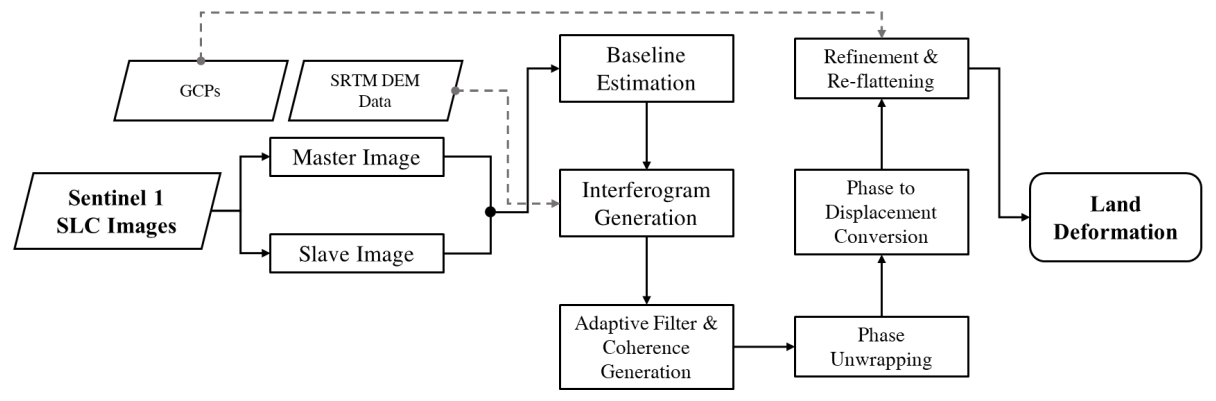

Fig. 2. Research workflow

\section{Results and Discussions}

This research aims to identify the region where suffered land deformation due to Cempaka TC in the karst landscape of Gunung Sewu by using the DInSAR method. The differential phase was obtained from a pair of Sentinel-1A satellite imageries which had been acquired on 15th November 2017 (before Cempaka TC) and 9th December 2017 (after Cempaka TC). This research result demonstrated the karst landscape of Gunung Sewu suffered land deformation due to Cempaka TC.

Based on the DInSAR method, the karst landscape of Gunung Sewu suffered land deformation in both of land uplifting and land subsidence. The land uplifting which occurred after Cempaka TC in the rate of $1-2 \mathrm{~mm} /$ year, meanwhile the land subsidence occurred in the rate of $-1--4 \mathrm{~mm} /$ year. The land subsidence had more dominant area $(75.25 \%)$ than the region of static karst and the region of land uplifting (Table 2).

Table 2. Land deformation area in karst landscape of Gunung Sewu

\begin{tabular}{cccc}
\hline Alteration & $\begin{array}{c}\text { Land Deformation } \\
\text { Rate }(\mathbf{m m} / \text { year })\end{array}$ & $\begin{array}{c}\text { Area } \\
\left(\mathbf{k m}^{2}\right)\end{array}$ & $\begin{array}{c}\text { Percentag } \\
\mathbf{e}(\mathbf{\%})\end{array}$ \\
\hline Uplifting & 2 & 9.01 & 0.69 \\
& 1 & 106.25 & 8.08 \\
\hline Static & 0 & 210.18 & 15.99 \\
\hline \multirow{3}{*}{ Subsidence } & -1 & 432.06 & 32.86 \\
& -2 & 369.14 & 28.08 \\
& -3 & 179.45 & 13.65 \\
& -4 & 8.60 & 0.65 \\
\hline
\end{tabular}

In a spatial perspective, there was a pattern of land deformation occurred in the karst landscape of Gunung Sewu was identified. The figure 3 shows the north region of Gunung Sewu experienced land uplifting with $115.26 \mathrm{~km}^{2}$ area and gradually altered to a static area 
with $210.18 \mathrm{~km}^{2}$ area on the middle and continuously transformed to land subsidence with $989.25 \mathrm{~km}^{2}$ area on the south region of Gunung Sewu. Furthermore, amongst of the land subsidence area, the highest rate of land subsidence ( $-4 \mathrm{~mm} / \mathrm{year})$ aglomerated on the southwest of Gunung Sewu karst landscape.

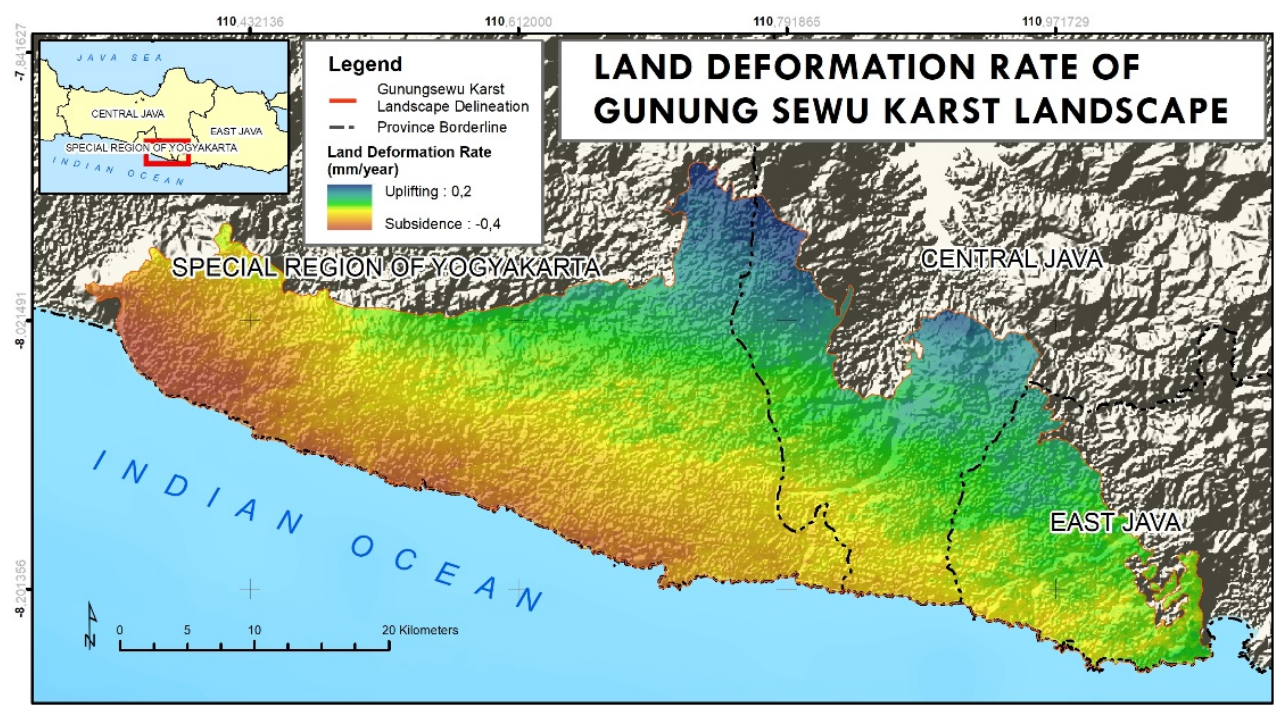

Fig 3. Land deformation rate in the karst landscape of Gunung Sewu

This research has an advantage of the land deformation detection result, which is relatively accurate and affordable [17]. Nevertheless, there was an inherent weakness of this study, it was the utilising of C-band channel of SAR upon the research area with has characteristics of rural and mostly covered by vegetation [39-41]. This problem could solve with L-band SAR (such as JERS-1 SAR, Alos Palsar-1, and Alos-2) [3,34,39,42]. Nevertheless, in the period of Cempaka TC (2017) was occurred, there is no L-band SAR satellite imagery freely available. Therefore, the utilising of C-band SAR as a data source is the best option in this research.

This research result has amplified the previous research result of land deformation was induced by hydrologically [5]. Moreover, the result also extended the previous finding that one of the hydrologic aspects which induced land deformation was extreme rainfall [5]. The land deformation rate finding was on low category, yet, this finding is necessary for hazardous weather impact identification of Gunung Sewu karst landscape.

In the future, mitigation and conservation of karst towards the hazards of massive land deformation caused by extreme rainfall is enable drawn up [6,22,43,44]. Further research should be conducted to identify a few factors affected the differentiation of land deformation rate in the karst landscape of Gunung Sewu. Besides of that, utilising of GNSS CORS as data source is needed to consider, it would improve the accuracy of land deformation detection and enrich the land deformation study, not merely limited on vertical deformation, yet also horizontal deformation $[18,19,45,46]$. 


\section{Conclusion}

Extreme rainfall affected by Cempaka TC occurred on 27-29th November 2017 in the karst landscape of Gunung Sewu. Rainfall besides as driven factor of karstification, also allegedly induced land deformation of karst landscape. The research result with DInSAR method indicated that extreme rainfall has induced land deformation in the karst landscape of Gunung Sewu in both form of land uplifting $\left(115.26 \mathrm{~km}^{2}\right)$ and land subsidence $\left(989.25 \mathrm{~km}^{2}\right)$. Spatially, the land deformation tended in the form of land uplifting $(1-2 \mathrm{~mm} /$ year $)$ in the north region and gradually transformed into land subsidence ( $-1--4 \mathrm{~mm} / \mathrm{year})$ in the south region. More comprehensive of understanding towards several factors which affected the distribution of land deformation rate is necessitous. Those matters could be a basis of karst conservation action and hazard mitigation towards extreme weather in the future.

We would like to say thank you to Satrio Indratmoko, S.Si., M.Sc (upon his software support) and Diah Fitri Novita Sari, S.Si (Upon her sharing of basic knowledge of land deformation on karst landscape).

\section{References}

1. S. Shanov and K. Kostov, in edited by J. W. LaMoreaux, 1st ed. (Springer, Heidelberg, 2015)., p. 131

2. A. Nicolas, Principles of Rock Deformation, 1st ed. (D. Reidel Publishing Company, Dordrecht, 1987)

3. Y. Aimaiti, F. Yamazaki, W. Liu, and A. Kasimu, Appl. Sci. 7 (2017)

4. C. B. Amos, P. Audet, W. C. Hammond, R. Bürgmann, I. A. Johanson, and G. Blewitt, Nature 509, 483 (2014)

5. E. Serpelloni, F. Pintori, A. Gualandi, E. Scoccimarro, A. Cavaliere, L. Anderlini, M. E. Belardinelli, and M. Todesco, J. Geophys. Res. Solid Earth 123, 4413 (2018)

6. F. G. Bourrouilh-Le Jan, Sediment. Geol. 118, 3 (1998)

7. A. Klimchouk, A. N. Palmer, J. De Waele, A. S. Auler, and P. Audra, Hypogene Karst Regions and Caves of the World (Spinger, Tuscaloosa, 2017)

8. R. A. Pambudi, A. Damayanti, and K. Marko, in Padjajaran Earth Dialogues, Int. Symp. Geophys. Issues (IOP Publishing, Bandung, 2019)

9. E. Fibriantika and R. I. Alhaqq, Meteorol. Dan Geofis. 19, 49 (2018)

10. H. H. Muhammad Najib Habibie, Sri Noviati, Meteorol. Dan Geofis. 19, 1 (2018)

11. F. Samrin, I. Irwana, Trismidianto, and N. Hasanah, IOP Conf. Ser. Earth Environ. Sci. 303, (2019)

12. Badan Nasional Penanggulangan Bencana, Data Bencana Indonesia 2017 (Pusat Data, Informasi, dan Humas Badan Nasional Penanggulangan Bencana, Jakarta, 2017)

13. K. Hazards, V. Andreychouk, P. S. Hazards, D. Karst, and I. Karst, 2, (2013)

14. D. Ford and P. Williams, Karst Hydrogeology and Geomorphology, 2nd ed. (John Wiley \& Sons Ltd, Chichester, 2013)

15. Y. Shi, Y. Tang, Z. Lu, J. W. Kim, and J. Peng, Geomatics, Nat. Hazards Risk 10, 1125 (2019)

16. Y. Gao, E. C. Alexander, and R. J. Barnes, Environ. Geol. 47, 1083 (2005)

17. H. Maître, in Process. Synth. Aperture Radar Images, edited by H. Maitre, 1st ed. (Wiley, Hoboken, 2010), pp. 279-299 
18. T. Bellone, P. Dabove, A. M. Manzino, and C. Taglioretti, Geomatics, Nat. Hazards Risk 7, 458 (2016)

19. V. Kaftan and A. Melnikov, in World Multidiciplinary Earth Sci. Symp., edited by M. Drusa, I. Yilmaz, M. Marschalko, I. Torok, O. Karaca, and A. M. Ferrero (IOP Publishing, Prague, 2017)

20. B. Osmanoğlu, F. Sunar, S. Wdowinski, and E. Cabral-Cano, ISPRS J. Photogramm. Remote Sens. 115, 90 (2016)

21. K. Fárová, J. Jelének, V. Kopačková-Strnadová, and P. Kycl, Remote Sens. 11, 1 (2019)

22. B. Tomaszewski, Geographic Information Systems ( GIS ); A Tool for Disaster Management (CRC Press, Boca Raton, 2015)

23. J. De Waele, F. Gutiérrez, M. Parise, and L. Plan, Geomorphology 134, 1 (2011)

24. E. Mulyana, M. B. R. Prayoga, A. Yananto, S. Wirahma, E. Aldrian, B. Harsoyo, T. H. Seto, and Y. Sunarya, MATEC Web Conf. 229, (2018)

25. R. W. Van Bemmelen, Geol. Indones. Volume IA, 637 (1949)

26. S. B. Kusumayudha, J. Setiawan, A. N. Ciptahening, and P. D. Septianta, J. Geol. Resour. Eng. 3, 1 (2015)

27. H. Samodra, S. Gafoer, and S. Tjokrosapoetro, Geological Map of the Pacitan Quadrangle (Bandung, 1992)

28. Surono, B. Toha, and I. Sudarno, Geological Map of the Surakarta-Giritontro Quadrangles (Bandung, 1992)

29. E. Haryono and M. Day, J. Cave Karst Stud. 66, 62 (2004)

30. R. A. Pambudi, A. Damayanti, and K. Marko, in E3S Web Conf. (EDP Sciences, Semarang, 2018), pp. 1-7

31. P. Potin, B. Rosich, N. Miranda, and P. Grimont, Procedia Comput. Sci. 100, 1297 (2016)

32. J. P. M. Boncori, Remote Sens. 8, 1 (2016)

33. X. Gao, Y. Liu, T. Li, and D. Wu, Remote Sens. 9, 741 (2017)

34. R. F. Hanssen, Radar Interferometry: Data Interpretation and Error Analysis (Kluwer Academic Publihers, New York, 2001)

35. Sarmap, SARscape Help Manual (Sarmap, Prague, 2014)

36. Exelis VIS, Getting Started with SARscape 5.4 (Sarmap, Tokyo, n.d.)

37. Sarmap, SARscape's Basic Module Tutorial (Sarmap, Prague, 2016)

38. Sarmap, 1 (2015)

39. J. M. Wempen and M. K. McCarter, Int. J. Min. Sci. Technol. 27, 159 (2017)

40. S. Takeuchi and S. Yamada, in Geosci. Remote Sens. Symp. (IEEE, Toronto, 2004), pp. 2379-2381

41. Z. Du, L. Ge, X. Li, and A. Hay-Man Ng, Remote Sens. 8, 1 (2016)

42. Sarmap, Sarscape Module (Sarmap, Prague, 2012)

43. M. J. Day, in Nat. Anthropog. Hazards Karst Areas Recognition, Anal. Mitig., edited by M. Parisse and G. John, 1st ed. (The Geological Society, London, 2007), pp. 172184

44. V. Tolmachev and M. Leonenko, in Karst Manag., edited by P. E. van Beynen, 1st ed. (Springer, Heidelberg, 2011), pp. 141-158 
45. A. Ustun, E. Tusat, and S. Yalvac, Nat. Hazards Earth Syst. Sci. 10, 1151 (2010)

46. B. Hu, J. Chen, and X. Zhang, Sensors 19, 1 (2019) 